Note

\section{Structure of Sescandelin-B, a New Metabolite Produced by the Fungus, Sesquicillium candelabrum}

\author{
Yasuo Kimura, Masahiko NaKadoI, \\ Hiromitsu NaKaJima, Takashi Hamasaki, \\ Takeo NaGaI, * Keisuke KoHmoto \\ and Atsumi SHIMADA \\ Department of Bioresource Science, \\ Tottori University, Koyama, \\ Tottori 680, Japan \\ * Department of Agricultural Chemistry, \\ Tottori University, Koyama, \\ Tottori 680, Japan
}

Received December 13, 1990

Sescandelin $(\mathbf{1})^{1)}$ has been isolated from the culture filtrate of Sesquicillium candelabrum IFO 30556 as a root-promoting substance which acts synergistically with IAA. In the course of our further search for new root-promoting substances from this fungus, we obtained a new compound named sescandelin-B (2) which did not show biologically activity itself. However, triacetyl sescandelin-B (3) at $100 \mu \mathrm{g} / \mathrm{ml}$ promoted root formation in Azukia cuttings ${ }^{2)}$ with 4 days of cultivation by about $40 \%$ over the control when IAA was applied on the second day, after applying 3 on the first day. In this paper, we describe the isolation and structural elucidation of this new compound 2 .

The fungus was statically cultured in a malt extract medium, the culture filtrate being treated with active charcoal at $\mathrm{pH} 2.0$, and successively extracted with acetone. The extract was concentrated and the residue was chromatographed on a silica gel column (benzene-acetone). The eluate with benzene-acetone $(9: 1)$ gave a mixture of 1 and 2. 2 was obtained by medium-pressure column chromatography on Kiesel $60 \mathrm{HF}_{254}$ gel eluting with benzene-acetone $(9: 1$ and $85: 15)$, and by preparative TLC on Kiesel $60 \mathrm{HF}_{254}$ gel, developing with benzene-acetone $(8: 2)$, in a yield of $3 \mathrm{mg} / 1$
The physicochemical properties of 2 were colorless plates (from $\mathrm{MeOH}$ ), mp $248-250^{\circ} \mathrm{C}$; UV $\lambda_{\text {max }}(\mathrm{EtOH}) \mathrm{nm}(\varepsilon)$ : $200(8500), 237(15,000), 244(17,000), 259$ (sh, 7800), 277 $(\mathrm{sh}, 6100), 290(\mathrm{sh}, 4100), 317(2300) ;$ IR $v_{\max }(\mathrm{KBr}) \mathrm{cm}^{-1}$. $3430,3210,1690,1650,1630,1605,1590,1250,1180$; EIMS $m / z(\%): 222\left[\mathrm{M}^{+}\right](100), 204(50), 180(68), 150(100)$. The molecular formula was determined by MS and elementary analysis (Found: $\mathrm{C}, 59.38 ; \mathrm{H}, 4.46$. Calcd. for $\mathrm{C}_{11} \mathrm{H}_{10} \mathrm{O}_{5}: \mathrm{C}, 59.46 ; \mathrm{H}, 4.54 \%$ ). A positive $\mathrm{FeCl}_{3}$ test together with the IR $\left(3210 \mathrm{~cm}^{-1}\right)$ and ${ }^{1} \mathrm{H}-\mathrm{NMR}$ spectra (in acetone- $d_{6}, \delta_{\mathrm{H}} 11.16$ ) indicated the presence of a chelated phenlic hydroxyl group. The signals at $\delta_{H} 6.62$ and $6.94(J=2.0 \mathrm{~Hz})$ revealed the presence of a pair of meta-coupling protons on a benzene ring. The vinyl methyl and hydroxymethyl protons appeared at $\delta_{\mathrm{H}} 2.24(3 \mathrm{H}, \mathrm{s})$ and $4.69(2 \mathrm{H}, \mathrm{s})$. The presence of a $-\mathrm{COO}$-group was suggested by the IR band at $1690 \mathrm{~cm}^{-1}$ and the ${ }^{13} \mathrm{C}$ signal at $\delta_{\mathrm{C}}$ 166.3. The UV spectrum of 2 was very similar to that of 6,8-dihydroxyisocoumarin ${ }^{3)}$ and superimposable on that of 1 .

By acetylation with $\mathrm{Ac}_{2} \mathrm{O}$-pyridine, 2 yielded a triacetyl sescandelin-B (3), as colorless needles (from acetone), $\mathrm{mp}$ $125-128^{\circ} \mathrm{C} ; \mathrm{UV} \lambda_{\max }(\mathrm{EtOH}) \mathrm{nm}(\varepsilon): 235(44,300), 259$ $(18,100), 266(18,600), 277(\mathrm{sh}, 15,000), 320(5600)$; IR $v_{\max }$ $(\mathrm{KBr}) \mathrm{cm}^{-1}: 2950,1790,1660,1620,1580,1380,1250$, 1200; HRMS m/z: $348.0850\left(\mathrm{M}^{*}, 348.0914\right.$ calcd. for $\mathrm{C}_{17} \mathrm{H}_{16} \mathrm{O}_{8}$ ). In the ${ }^{1} \mathrm{H}-\mathrm{NMR}$ spectrum of 3 , the downfield shifts of a pair of meta-coupling protons of 2 (from $\delta_{\mathrm{H}} 6.62$ and 6.94 to 6.94 and 7.21 , respectively) indicated the phenolic hydroxyl groups being adjacent to those protons.

Catalytic hydrogenation over $\mathrm{PtO}_{2}$ of 2 gave a derivative (4) as colorless crystals, mp $194-196^{\circ} \mathrm{C}$; UV $\lambda_{\max }(\mathrm{EtOH})$ nm $(\varepsilon): 200(39,000), 205$ (sh, 34,800), $214(\mathrm{sh}, 27.700)$ 228 (sh, 18,200), $266(47,000)$; IR $v_{\max }(\mathrm{KBr}) \mathrm{cm}^{-1}: 3200$, $1650,1590,1480,1400,1290,1260,1200,1$ I 80 ; HRMS $m / z: 208.0754\left(\mathrm{M}^{+}, 208.0736\right.$ calcd. for $\left.\mathrm{C}_{11} \mathrm{H}_{12} \mathrm{O}_{4}\right)$.

The ${ }^{1} \mathrm{H}$-NMR spectrum showed the presence of two methyl groups $\left[\delta_{\mathrm{H}} 1.27(3 \mathrm{H}, \mathrm{d}, J=6.0 \mathrm{~Hz}), 1.48(3 \mathrm{H}, \mathrm{d}\right.$, $J=6.0 \mathrm{~Hz})]$, and two methine protons $\left[\delta_{\mathrm{H}} 2.99(\mathrm{IH}, \mathrm{dq}\right.$ $J=6.0,3.0 \mathrm{~Hz}), 4.77(1 \mathrm{H}, \mathrm{dq}, J=6.0,3.0 \mathrm{~Hz})]$ newly appeared. Furthermore, the signal at $\delta_{\mathrm{H}} 4.77$ was coupled to those at $\delta_{\mathrm{H}} 1.48$ and 2.99 , and the signal at $\delta_{\mathrm{H}} 2.99$ to that at 1.27 by decoupling experiments. From these results, 4 had a partial structure of $-\mathrm{O}-\mathrm{CH}\left(\mathrm{CH}_{3}\right)-\mathrm{CH}\left(\mathrm{CH}_{3}\right)$. Since the ${ }^{1} \mathrm{H}-\mathrm{NMR}$ spectrum $\left[\delta_{\mathrm{H}} 2.24,(3 \mathrm{H}, \mathrm{s}): 4.69,(2 \mathrm{H}\right.$, s)] of 2 showed the presence of vinyl methyl and hydroxymethyl groups, one of the two methyls in 4 must<smiles></smiles><smiles>[R9]Cc1c(C)oc(=O)c2c(O[R])cc([R])cc12</smiles>

$2 R=H$ $3 R=A C$<smiles>CC1OC(=O)c2c(O)cc(O)cc21</smiles> 
Table I. PROTON AND CARBON NMR DATA FOR SESCANDELIN-B (2)

\begin{tabular}{ccc}
$\begin{array}{c}\text { Carbon } \\
\text { no. }\end{array}$ & $\delta_{\mathrm{H}}$ & $\delta_{\mathrm{C}}$ \\
\hline $\mathbf{1}$ & & 166.3 \\
$\mathbf{3}$ & & 152.7 \\
$\mathbf{4}$ & & 114.1 \\
$\mathbf{4 a}$ & & 140.8 \\
$\mathbf{5}$ & $6.94 \mathrm{~d}(2.0)^{a}$ & 102.6 \\
$\mathbf{6}$ & & 167.5 \\
$\mathbf{7}$ & $6.62 \mathrm{~d}(2.0)^{a}$ & 102.3 \\
$\mathbf{8}$ & & 164.6 \\
$\mathbf{8 a}$ & & 99.7 \\
$\mathbf{9}$ & $2.24 \mathrm{~s}$ & 16.7 \\
$\mathbf{1 0}$ & $4.69 \mathrm{~s}$ & 57.2 \\
$\mathrm{OH}$ & $11.16 \mathrm{~s}$ & \\
\hline
\end{tabular}

${ }^{13} \mathrm{C}(67.80 \mathrm{MHz})$ and ${ }^{1} \mathrm{H}(270.05 \mathrm{MHz})$ in $\mathrm{CD}_{3} \mathrm{COCD}_{3}$.

a Coupling constants in $\mathrm{Hz}$.

have been derived from a hydroxymethyl group bonded to a double bond in 2 by hydrogenolysis. ${ }^{4)}$

In the NOE difference spectrum of 3 , irradiation of the signal at $\delta_{H} 7.21$ due to an aromatic proton gave rise to an enhanced signal at $\delta_{\mathrm{H}} 5.09$ due to methylene protons, but not to that at $\delta_{\mathrm{H}} 2.39$ due to methyl protons. Also, irradiation of the methylene protons at $\delta_{\mathrm{H}} 5.09\left(\mathrm{C}_{10}\right)$ caused NOE of the resonance at $\delta_{\mathrm{H}} 2.39\left(\mathrm{C}_{9}\right)$ and $7.21\left(\mathrm{C}_{5}\right)$.

The signals of the ${ }^{1} \mathrm{H}$ - and ${ }^{13} \mathrm{C}$-NMR spectra of 2 were correlated by selective proton decoupling experiments and by comparing with those of $1{ }^{11}$ Thus, the structure of 2 was elucidated to be 6,8-dihydroxy-4-hydroxymethyl-3methyl-isocoumarin.

The structure-activity relationship among 1, 2 and their derivatives to Azukia cuttings, together with biosyntheses of 1 and 2 will be reported in the near future.

Acknowledgments. The authours thank Messrs. Y. Wakai and $\mathrm{H}$. Hirano for their technical assistance. This work was supported in part by a Grant-in-Aid for Scientific Research (No. 63440010) from the Ministry of Education, Science and Culture of Japan.

\section{References}

1) Y. Kimura, H. Nakajima and T. Hamasaki, Agric. Biol. Chem., 54, 2477 (1990).

2) M. Mitsuhashi, H. Shibaoka and M. Shimokoriyama, Plant and Cell Physiol., 10, 715 (1969).

3) Y. Furutani, H. Naganawa, T. Takeuchi and $H$. Umezawa, Agric. Biol. Chem., 41, 1179 (1977).

4) M. C. Dart and H. B. Henbest, J. Chem. Soc., 1960, 3563. 